\title{
Global Management is Truly Derived from Economics
}

\section{Rudrarup $\mathbf{G}^{*}$}

Commercial Manager of Multifarious Projects Group, India and Overseas Editor/Reviewer of American Institute of Science, USA

*Corresponding author: Rudrarup G, Commercial Manager of Multifarious Projects Group, India and Overseas Editor/Reviewer of American Institute of Science, USA, Tel: 9831922177; E-mail: rudrarupgupta21@gmail.com

Received date: August 26, 2016, Accepted date: August 29, 2016, Published date: August 31, 2016

Copyright: @ 2016 Rudrarup G. This is an open-access article distributed under the terms of the Creative Commons Attribution License, which permits unrestricted use, distribution, and reproduction in any medium, provided the original author and source are credited.

Citation: Rudrarup G (2016) Global Management is Truly Derived from Economics. J Glob Econ 4: e110. doi:10.4172/2375-4389.1000e110

\section{Editorial}

The term "Global Management" is having a wide interpretation in all over the Globe. Global Management always denotes the indelible glimpse of a business, where the commercial dealings are the first and foremost priority in between buyer and seller not only to maintain the needful goodwill in a different dimension.

Now a day plenty of Academic Institute provides the high-end training about the Global Management and they throw the light about the real actuality of Management in the perspective of our present day business. Because management has the massive responsibility to regulate the business right from the execution to operation, where each individual, who are associated in that very business must be concerned regarding the noteworthy business strategy.

Therefore it is quite true that, the real advancement of technology has been popularized enormously in all over the World. So as a result any organization can have the best opportunity to regulate their business in a global channel already. So that, they can be reached to another nation just within a blink of an eye through the best business dealing in deed. Economical magnificence has the very promising role out here.

Global management is in a prior position to realize the upcoming commercial happenings and the near future consequences to run the business. So they need the business economy, great business infrastructure, detailed monitoring, and proper supervision and so on. Moreover in an International Business both community and culture are really pivotal to make it successful in all the regards.

But we have an economical barrier always. Because we have excel the business with the stipulated fund at all. So Global Perspective denotes the accelerated flow and the stunning co-ordination with another country. This managerial coordination ensures the best commercial environ and the comprehensive celerity of a successful business.

Both Economics and Management are interrelated with each and other to entrench the great business paradigm now. Actually Economics shares the wide activities of an organization and on the other hand Economics regulates the painstaking organizational function and at the same point of time that very function is entirely administered by that management.

- Leadership: It is absolutely very important from the perspective of global prominence. So community leadership approach is implemented out here. Because in this domain leaders do ensure the common organizational goal with an infinite hope and prosperity.

- Warm Decision: Any solid decision is able to find the best destiny of a business in deed. The solidity of a business goal largely depends upon the business decision in a befitting manner.

- Communal Effort: It is one of the best business movements. Because for a warm business the community formation is absolutely essential and trust worthy, this is ever true.

- Perception: From the point of view of Economics business perception is truly pivotal at all. All the global leaders shall have to understand the actual insignia of business because a number of employees are leading their life just through that business in terms of money and recognition.

In this regard both Economics and Management are two very crucial attributes for a magnificent enrichment, which needs the class act with an inextinguishable transparency ever. 